\title{
Hypertrichosis and dwarfism in a painting of Agostino Carracci (1598-1600)
}

\author{
C. M. Oranges ${ }^{1} \cdot$ M. Matucci-Cerinic ${ }^{2}$
}

Received: 27 April 2015 / Accepted: 30 April 2015 / Published online: 14 May 2015

(C) Italian Society of Endocrinology (SIE) 2015

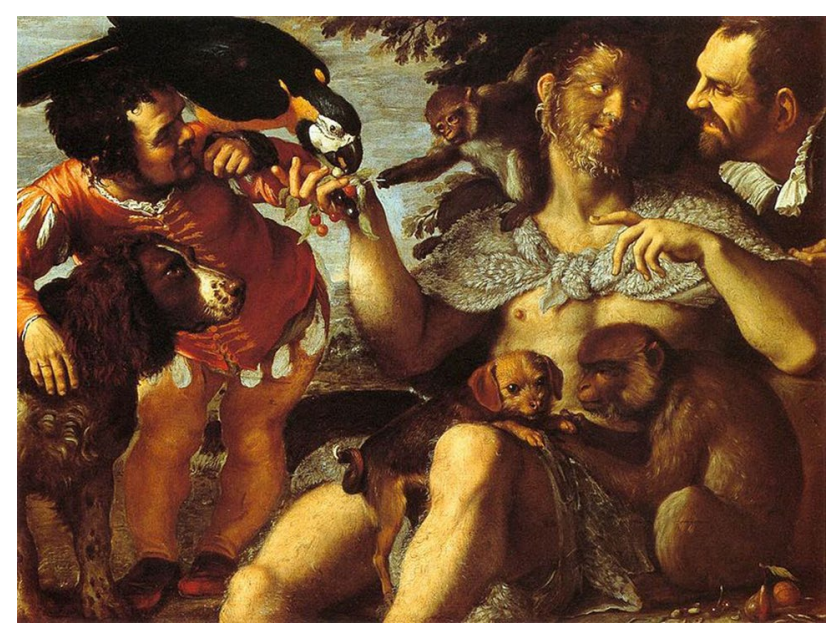

Agostino Carracci (Bologna 1557-Parma 1602) was an Italian painter and printmaker, brother of the more famous Annibale and cousin of Lodovico Carracci. With his gritty representation of the nature, he is considered one of the most important forerunners and inspirers of the art of Caravaggio.

This picture titled "Triplo ritratto di Arrigo peloso, Pietro matto e Amon nano" (Triple portrait of hairy Harry, mad Peter and tiny Amon) is an oil painted in a wood panel dated 1598-1600, commissioned by cardinal Odoardo

C. M. Oranges

studioranges22@gmail.com

1 Plastic, Reconstructive and Aesthetic Surgery School, Marche Polytechnic University, Ancona, Italy

2 Division of Rheumatology, Department of Clinical and Experimental Medicine, AOUC, University of Florence, Florence, Italy
Farnese from Ferrara and exposed in the National Museum of Capodimonte in Naples.

The work represents three bizarre valets that lived at the court of the Farnese family [1]. On the left side of the picture is represented a man affected by dwarfism, called Amon. More interestingly, at the center of the group, is portrayed Arrigo, a young man suffering from hypertrichosis universalis. Arrigo belonged to the population of Guanches, the aboriginal inhabitants of the Canary Islands, often victims of raids by French pirates and abducted to serve in Europe. In his family, several members were affected by hypertrichosis and engaged as valets by European noble families [2].

Conflict of interest None.

Ethical approval This paper does not contain any studies with human participants or animals performed by any of the authors.

Informed consent No informed consent.

\section{References}

1. Zapperi R (1985) Arrigo le velù, Pietro le fou, Amon le nain et autres bêtes: autour d'un tableau d'Agostino Carrache. Ann Econ Soc Civilis 40:307-327

2. Martino E (2010) Endocrinology and art. Portrait of Antonietta Gonzales Lavinia Fontana de Zappis (1552-1614). J Endocrinol Invest 33(7):511 